\title{
Advancing capacity to adapt to climate change in the Australian property industry - addressing climate change information needs
}

Warren-Myers, G., Hurlimann, A. and Bush, J. (2020), "Advancing capacity to adapt to climate change: addressing information needs in the Australian property industry", Journal of European Real Estate Research, https://doi.org/10.1108/JERER-03-2020-0017

Purpose: To understand the sources of climate change information used and trusted by key stakeholders in the Australian property industry, their information needs, and their capacity to translate that information into decision making.

Design/methodology/approach: Qualitative research applying in-depth interviews with 24 key stakeholders from a diverse range of property / real estate companies in Australia.

Findings: The research identified a wide range of information types used by key stakeholders, ranging from reliance on unsophisticated mass media reporting to detailed analysis of scientific research. The capacity of stakeholders to translate this information for their organisation was polarised 11 of the 24 interviewees indicated they had the capacity, whilst the other 13 indicated they did not, often due to time horizons or lack of current interest within the organisation or from clients.

Research limitations/implications: The research was limited to 24 in-depth interviews, and is not intended to be a representative sample. However this limitation is off-set by the fact that a diverse range of stakeholders were interviewed, and an in-depth and rich understanding has been provided about their approach to climate change.

Practical implications: The results can inform the development of better communication channels for climate change for the property industry by supporting science-practice collaborations in the timely and effective dissemination of research. This is important to understand given the identified need to bridge the gap between research, policy and practice.

Social implications: Climate change poses significant challenges and risks for built environments. The property industry as a key stakeholder has great potential to influence current practices. The results reported here assist in addressing these challenges.

Originality/value: At present, limited research globally has been conducted about climate change actions in the property industry. This research responds to this gap.

Key words: climate change; adaptation; real estate; property, information; communication; Australia; science-policy interface 


\section{Introduction: climate change and the Australian property industry}

Climate change is currently impacting the property industry in many locations across the world, with impacts anticipated to increase as climate change intensifies. Property, at its core, provides places for shelter, employment and provision of services, which are largely provided in the built environment. Given over $50 \%$ of the world's population now lives in urban areas (UN-HABITAT 2011), and that built environments account for between $40-70 \%$ of greenhouse gas emissions (UN-HABITAT 2011), the property industry could play a key role in climate change mitigation, and ensure built environments are well adapted to climate change now, and in the short and long term.

Climate change projections indicate that a 'business-as-usual' scenario is likely to result in $3 \cdot 2-5.4^{\circ} \mathrm{C}$ of warming by 2100 (Fuss et al. 2014). The Intergovernmental Panel on Climate Change (IPCC) has identified that individual national targets made under the Paris Agreement (United Nations 2015) are not sufficient to reach the global aim of limiting warming to $1.5-2.0^{\circ} \mathrm{C}$ above pre-industrial levels (IPCC 2018; UNEP 2019). This paints a challenging picture for built environments. Climate change impacts will vary across locations, but potentially include a combination of: sea level rise, increasing temperatures, increased bushfire risk, changing rainfall patterns giving rise to increasing periods of drought, and flash flooding.

In addition to present effects on the property industry (with $1^{\circ} \mathrm{C}$ of warming already occurring to date (IPCC 2018)), climate change will affect the industry in multiple ways into the future, and decisions made now can influence how resilient those assets and society can be. These future impacts will require different approaches to current investment management, development, acquisition and divestment of assets, and these new approaches need to begin now to ensure built environments are well adapted, and to minimise losses.

In Australia the impacts of climate change for the built environment were detailed in a 2019 report by the Cross Dependency Initiative which estimated that 383,300 properties in Australia are at high risk from climate change impacts, increasing to 735,654 properties by 2100 (for existing development only) (Mallon et al. 2019). Properties and their owners, investors, occupiers and users, can be affected by climate change in a multitude of ways. The implications will be felt financially, environmentally and socially. While a decade of greater attention to sustainability and corporate social responsibility have driven some changes in the Australian property sector, this has mostly been at an institutional scale rather than individual household level. Limited national action is being taken on climate change in Australia from a policy and governance aspect, despite the Reserve Bank of Australia, the Australian Prudential Regulation Authority and the Climate Council providing warnings that climate change poses serious economic risks, to which property institutional owners and companies need to examine their exposures, and provide information to investors, occupiers and users of their assets (Ryan 2019).

Some actors in the Australian property industry have instigated energy efficiency actions which can assist in addressing climate change mitigation. Action was motivated by the introduction of mandatory disclosure of 'Building Energy Efficiency Certificates' (BEEC) for commercial properties over $1000 \mathrm{~m}^{2}$ when offered for lease or sale, through the national Commercial Building Disclosure program (CBD), which began in 2010. This has seen substantial increases in the reporting and assessment of National Australian Built Environment Rating System (NABERS) energy ratings for commercial buildings, which comprise part of the BEEC (Warren-Myers 2016). Further, this has also demonstrated an improvement in the buildings rated, where area-weighted average NABERS energy ratings were found to have increased to 4.42 stars in 2019 up from 3.63 in 2012 (Commercial Building Disclosure Program 2019). However, a broader understanding of the implications of climate change on property assets and adaptation to these impacts, is less understood.

Research to understand actions to address climate change in the property industry is limited. Storbjörk et al. (2018) explored how Swedish property developers were responding to climate change through urban planning. Their study with seven key actors in the industry found little evidence that property developers were pursuing ambitious climate change agendas. Rather, they found that government 
regulation (including urban planning) was a key catalyst for action. The study did not look deeply into information sources and needs. A study in the south-east Queensland area of Australia explored how the institutional structure of the housing industry influences climate change, through a survey, interviews and focus groups, drawing upon a range of actors in the built environment (e.g. architects, solicitors, consultants and government), not just developers (Shearer et al. 2016). While the study did not focus on information needs and sources, it did find that a number of small consulting firms had very low levels of climate change knowledge, and did not perceive it to be a risk. Smaller developers were found to rely on consultants for activities such as due diligence. Taylor et al. (2012) conducted an exploratory survey of 45 members of the development industry in Australia (developers, investors and advisory/technical service providers), and an additional 11 interviews. The study did not investigate information needs or sources. They found that climate change was a low priority for participants. The participants perceived that they had capacity to adapt in the medium term, but were unsure what would be necessary to do so. Regulatory controls were seen as a way of motivating action on climate change, but were not a preferred option.

As part of the research project reported in this paper, Warren-Myers et al. (2020) identified a range of barriers and challenges to climate change action present in the Australian property industry. These were: climate change information challenges including a lack of communication of information; ignorance of climate change facts, and bias/untrustworthy sources of information; a focus on financial challenges; and the absence of government policy and leadership, which was also identified as a barrier to climate change action in the Australian construction industry (Hurlimann et al. 2018b).

This paper addresses this knowledge gap by exploring the Australian property industry's climate change information needs. This is an important area of research given that informing public policy through high impact research is critical for effective decision making (The British Academy 2008), and applies to policy-making by both public institutions and private companies. Yet, while many practitioners claim to be supportive of the use of evidence in decision making, their actual use is patchy (Head 2016). This paper addresses the following questions in the Australian property sector:

1) What sources of information are used (if any) to keep abreast of climate change?

2) What types of information would be most useful, and in what formats?

3) Do the property stakeholders have the capacity to translate this information into practice?

The paper proceeds with a review of climate change information needs for the property industry, before detailing the research method undertaken, then presenting and discussing the results obtained, before drawing conclusions.

\section{Climate change information needs}

Scientific evidence about the nature, extent and impacts of climate change has existed for decades. Yet despite this, action to address this problem has fallen well short of the scale needed to limit warming, and thus avoid dangerous and irreversible climate change (IPCC 2018). Some argue that this is in part due to the science-policy gap (van den Hove 2007), that is the insufficient communication of the science of climate change, to those implementing policy. Others suggest it is because large scale or global problems like climate change are often complex, and have more than just 'scientific knowledge' to be considered. Head (2008 p.5), describes three important types of knowledge that inform policy: "political know-how; rigorous scientific and technical analysis, and practical/professional experience." It is argued that a strong interface between science and policy is needed, in which climate scenarios are well communicated to policy makers to facilitate effective adaptation policy (Iyalomhe et al. 2013).

These gaps between scientific evidence, and practice can be present for both policy makers and practitioners. One study on the production of vulnerability assessment reports found deficiencies in both science and policy domains, with researchers not effectively translating research into an easily accessible format, and practitioners insufficiently engaging with academic research (Weichselgartner and Kelman 2014). There were a number of factors identified as inhibitors to joint problem identification and framing between those producing the knowledge and the decision makers. These include functional, structural 
and social factors. Others have found that despite the availability of scientific information, the political nature of policy making and other implementation realities interferes with translation into policy implementation (Dunn et al. 2017; Taylor and Hurley 2016; van Stigt et al. 2015). These studies identify important ways for the science-policy interface to be strengthened, including greater integration between knowledge producers and knowledge users, linking research with practitioner identified problems, greater accessibility of information, and the framing of information. Tribbia and Moser (2008), in their research into information needs of coastal managers in the USA, found that scientific knowledge and local knowledge were not widely used sources of information. Rather, interpersonal communication channels and media were important sources. In comparison, a study of adaptation in the Norwegian housing sector found that industry associations and networks and national standards were important sources of information (Eriksen et al. 2009).

Howlett (2014) has found that the characteristics of climate change as a public policy problem bring particular challenges to addressing it. In many contexts climate change has 'low visibility and low intentionality' which allows governments to implement negative strategies of denial and attack, rather than positively addressing the policy problem (Howlett 2014 p.401). As discussed by Howlett, in many instances, governments are not held by populations as being solely responsible for climate change, thus they are motivated only to respond in short term or periodic activities which are largely symbolic. For people living in areas not susceptible to climate change, its impact is muted compared with countervailing issues such as economic health (Howlett 2014).

In Australia, Hurlimann et al.'s (2018a) study into climate change adaptation in the Australian construction industry identified information challenges and needs (Hurlimann et al. 2018a). Their study interviewed 21 key actors, and found that less than half indicated they keep abreast of climate change developments. A diverse range of climate change information sources was found to be drawn upon, with the Commonwealth Scientific and Industrial Research Organisation (CSIRO) the most trusted source of information cited by the participants. They identified three types of climate change information that would be useful to them that would create greater certainty: future weather conditions; legislation, regulations and codes; and emerging trends and projects. A review of literature on approaches to enhancing the use of research from social sciences by Walter et al (2003) categorised eight interventions to enhance the impact of research. These include: dissemination in accessible forms, educational interventions, social influence, collaborations between researchers and end users, incentives to change practice, reinforcement of behaviour, facilitation to support change, and multifaceted interventions involving implementation of two or more of these (Walter et al. 2003 p.12).

More generally, in the field of public policy, it has been found that policy makers often ignore academic research as their organisations did not place a high value on this type of research (Head 2016). Instead, it was found that commissioned or internally conducted research was perceived to be more relevant and timely (Head 2016). A review of literature found that only a small number of practitioners utilise academic research. Barriers were found to include a lack of: access to the research; time to access and read; skills to interpret and a perception that it is not user friendly (Walter et al. 2003).

While no academic papers about climate change information needs in the Australian property industry have been published, there is also a lack of practitioner information specific to the property industry. The Property Council of Australia in its submission to a review of the Federal Climate Change Act noted the key information challenge of limited information currently existing in a singular format that "can synthesise climate change scenarios, regional risk, weather and location specific data...will help (property) practitioners understand the implications of climate change...and develop strategies accordingly" (Property Council of Australia 2015). This research aims to address the gap in research identifying climate change information needs in the Australian property industry. This research could also contribute to more effectively targeted development of practitioner information.

\section{Research approach}


The aim of this paper is to identify and understand the types of information, the sources and the capacity for translation of that information for business practices in the Australian property industry. The objective is to identify opportunities for improvement of sources, types of information and the capacity for the Australian property industry to then translate this information into useful resources to inform business practice. The research has focused on high-level staff within the range of property organisation and companies in the Australian property industry. The research method is described hereafter.

\section{Participants}

Twenty-four key stakeholders in the Australian property industry were interviewed in 2018 and 2019. Interviewees were purposively recruited from a variety of sectors across the property industry, and from various Australian locations, predominately Melbourne and Sydney, based on where the head office is situated, yet operations were generally Australia-wide. A number of people invited to participate in the study indicated they were not 'ready' with their climate change plan and declined to be interviewed, despite this not being a requirement for interview. Others who declined the invitation indicated they were not interested. Thus, there is potential for our sample to be skewed to those more active in their response to sustainability and climate change. Participants recruited were from various types of Australian property industry organisations and firms, including Australian Real Estate Investment Trusts, unlisted trusts or funds, superfunds, development groups, funds and trusts, one high net worth family, a range of consultancy firms providing property services to other stakeholders and one industry body. Table 1 provides an outline of those interviewed and the sector in which they operate. Sector level information only is used to report the results for each participant, in line with the human research ethics protocol for participant confidentiality determined for the research.

Table 1. Australian key property stakeholder interviewee details

\begin{tabular}{|c|c|c|}
\hline Type of stakeholder & $\begin{array}{l}\text { Number of } \\
\text { participants }\end{array}$ & Property sectors \\
\hline $\begin{array}{l}\text { RE: Australian Real Estate Investment } \\
\text { Trusts (AREITS) / Unlisted trusts or funds }\end{array}$ & 11 & $\begin{array}{l}\text { Diversified, retail, commercial } \\
\text { office, industrial, residential }\end{array}$ \\
\hline S: Superfunds & 2 & Diversified \\
\hline DEV: Development Group/Fund/Trust & 5 & $\begin{array}{l}\text { Diversified, residential, } \\
\text { affordable \& student housing }\end{array}$ \\
\hline HNW: High Net-worth Family & 1 & Commercial and residential \\
\hline $\begin{array}{l}\text { ADV: Advisory / Consultancy Firm or } \\
\text { Company }\end{array}$ & 4 & Diversified \\
\hline I: Industry Bodies & 1 & Diversified \\
\hline Total & 24 & \\
\hline
\end{tabular}

\section{Interview design}

The design of the semi structured interviews utilised Moser and Leurs' (Moser and Luers 2008) climate change risk preparedness framework, which has been applied in multiple contexts including the Australian construction industry (Hurlimann et al. 2019). The framework was adapted to investigate the property industry's climate change awareness, analytical capacity and actions. In line with the research question articulated earlier, this paper focuses on results relating to climate change information sources and their use. Thus, interview questions followed Tribbia and Moser (Tribbia and Moser 2008), including: a) how respondents keep abreast of climate change developments; b) where they source this information, c) what sources they trust the most, d) what they would find to be useful climate change information sources, and e) their capacity to translate such information into daily organisational practice.

\section{Data collection and analysis}

The semi-structured interviews were approximately between 30 to 60 minutes in duration, and were conducted either in person or via the phone. Interviews were mostly digitally recorded then transcribed by a professional transcription company. Four interviews were not recorded at the interviewees' request, 
thus comprehensive notes were taken for these. The responses were analysed using NVivo 11, with both content and thematic analysis undertaken. The coding process adopted involved a single coder doing the initial coding of the results, with a second researcher reading and listening to the interviews and reviewing and adding to the coding undertaken. In addition, the second researcher contributed to the understanding of the content analysed, and was able to review in a broader context identifying linkages between codes and also the broader themes of the research. This then provided a comprehensive approach to generate a detailed content analysis of coding utilising the NVivo program, with increased depth and breadth of thematic analysis that drew together linkages across different stakeholder groups and individuals. The results are discussed below.

\section{Limitations}

The purposively sampling of Australian property industry stakeholders may bias the results of this research, and the reporting of findings for this research should not be construed that this is a representation of the whole Australian property sector. Particularly, as many of those approached, declined due to their in-action, lack of interest or had recently realised they should be doing something and had suggested we ask them in a year. Consequently, the findings may present a more positive perspective of climate change engagement and action in the Australian property industry. In addition, this research has only focused on the private sector, no government ownership representatives were interviewed for this research.

\section{Results and discussion}

The results of the analysis are concurrently presented and discussed below in line with the three research questions explored.

\section{Climate change information types and sources}

Interviewees were asked how they keep abreast of climate change information, and what sources they use to do so. The responses indicate that a broad range of climate change information sources are utilised in the activities of those interviewed. Generally, the respondents indicated they kept up to date in some form with climate change information, although there were six who did not (two REs, one developer, one advisory firm, the industry body and the high net-worth family).

"I'm being brutally honest here. So, we don't get a lot of information on climate change." (RE1)

The others relied upon information from a variety of sources, including a number of respondents who stated multiple ways in which they sought to keep abreast of climate information. The most popular forms to stay up to date with information were through industry committees or networks (12), with national and international media (8) the second most popular form, continuing professional development (CPD) (4), field-specific publications (2), consulting groups (2) and the stock exchange (2), with newsletter (1) and social networks also mentioned (1). This multitude of information sources is consistent with previous built environment studies discussed earlier (Hurlimann et al. 2018a; Tribbia and Moser 2008). It is also consistent with research showing a preference for engaging consultants rather than directly using academic research (Head 2016). However, these results are not wholly consistent with the mechanisms found in literature to facilitate effective dissemination of research into decision making: dissemination in accessible forms, educational interventions, social influence, collaborations between researchers and end users, incentives to change practice, reinforcement of behaviour, facilitation to support change, and multifaceted interventions (Walter et al. 2003 p.12). The role of industry bodies, committees, networks and the requirements of 'continuing professional development' (CPD) suggest that industry bodies have a pivotal role in assisting the industry to stay up to date with current climate change information.

The ways the information is sourced by each stakeholder was categorised. The types of information, and means for sourcing this information varied substantially across the different organisations. It was identified that 7 interviewees were actively searching for advanced/sophisticated and reputable 
(scientific or research-based) climate change information (usually from government, the Intergovernmental Panel on Climate Change, or respected scientific organisations, like the Commonwealth Scientific and Industrial Research Organisation - the CSIRO) in detailed and targeted ways, 6 were actively searching for climate change information from a range of reputable sources, and 4 were watching or reading climate change content from readily accessible media only. There were 7 who made minimal or no attempts to intentionally source climate change information.

Figure 1. Australian key property stakeholder investigative approaches to climate change information (Source: Authors, 2020)

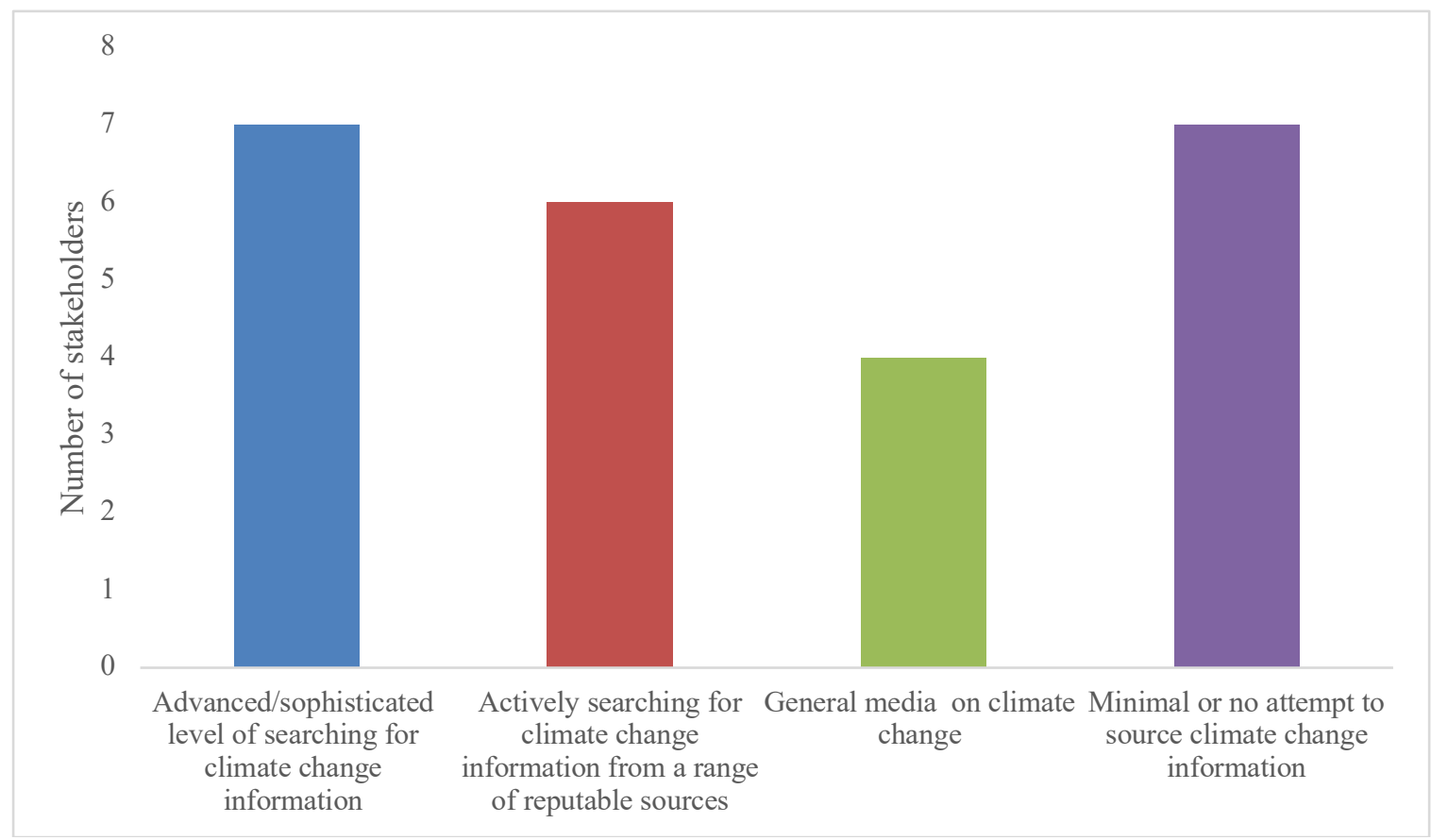

\section{Trusted sources of information about climate change}

Interviewees were asked about what sources of information they trust most. Whilst there are a broad range of information types and sources utilised by the different stakeholders as indicated in Table 2, the trusted sources included international scientific sources, through to industry bodies and consultants. It was found that industry rating tool organisations were the most favoured and trusted sources of information (29), followed by government led information and resources (19), international research and organisations (16) and industry consultants (mostly unspecified), industry bodies (12) and academia (11). The specific sources of trusted information are shown in Table 2. Again, this indicates that for those interviewed, non-academic sources of information were preferred, compared to more applied and directed forms of research and information, which has been found to be preferred in other policy contexts (Head 2016; Walter et al. 2003). 
Table 2. Trusted sources of information for key Australian property industry interviewees (Source:

Authors, 2020)

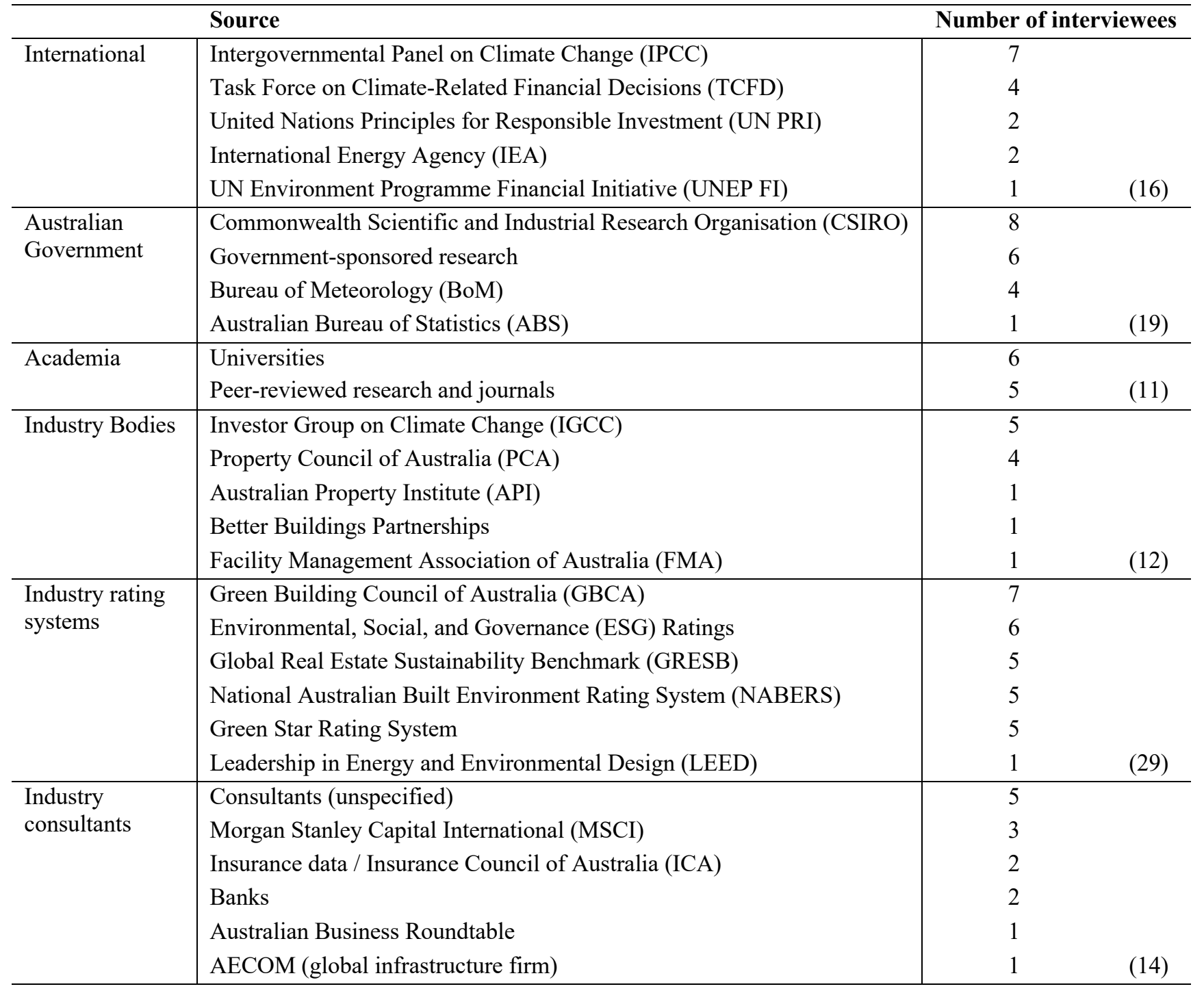

In comparison to research conducted in the Australian construction industry (Hurlimann et al. 2018a), there are a larger number of trusted sources of climate change information identified, and these sources are much more diverse. Similar to the Australian construction industry, the CSIRO information was the most stated (8), however, overall industry rating systems (organisations) were a dominant trusted information source.

\section{Types of information about climate change that the respondents would find useful}

Participants were asked about the types of information they found most useful. Broadly, the interviewees wanted better information for predicting the effects that climate change will have (9) (similar to US research for coastal managers (Tribbia and Moser 2008)), and specifically, a desired need for scenario mapping (7), cost-benefit analyses (4), ability to examine assets individually and across the portfolio (1), with this information to be provided by credible sources and utilised / accessed on a national level (4). The second theme reflected in the data analysis was the role of government/s in providing clarity through standards (2) and legal or mandated requirements applied at the asset level (2). There was a clear expectation for a collaborative approach between industry and government in the development of international or universal standards, this desire for standards to be developed in conjunction with 
industry. Hurlimann et al. (2018b) also found that the Australian construction industry also sought greater guidance in the form of standards that needed to be developed, preferably in collaboration with the construction industry. Taylor et al.'s (2012) and Storbjörk et al's (2018) studies in the Australian and Swedish property industry respectively, also found an important role for regulation in guiding developers about climate change. Providing a national framework would support and facilitate asset assessments, tracking and comparisons within portfolios and across funds, and also build familiarity with actions and technology in response to climate change challenges. The strong focus of respondents on utilising industry based rating tools and their websites as a key form of information source and guidance, also suggests that there is opportunity for market leading tools to be developed to drive best practice. Whilst standards developed by government can build minimum standards and increase compliance, as has been shown in the industry utilisation of industry rating tools Green Star (voluntary) and the NABERS scheme (as part of the national mandatory disclosure program), that has influenced and changed perception, uptake and utilisation by property stakeholders (Warren-Myers, 2016).

\section{Current capacity of respondent's organisation to translate information into practices}

The analysis of whether the utilisation of information about climate change could then be translated into meaningful communication or action strategies in the operational side of the organisation, met with a rather polarising yes or no, as shown in Figure 2.

Figure 2. Australian key property stakeholders' capacity to translate climate change information into practice (Source: Authors, 2020)

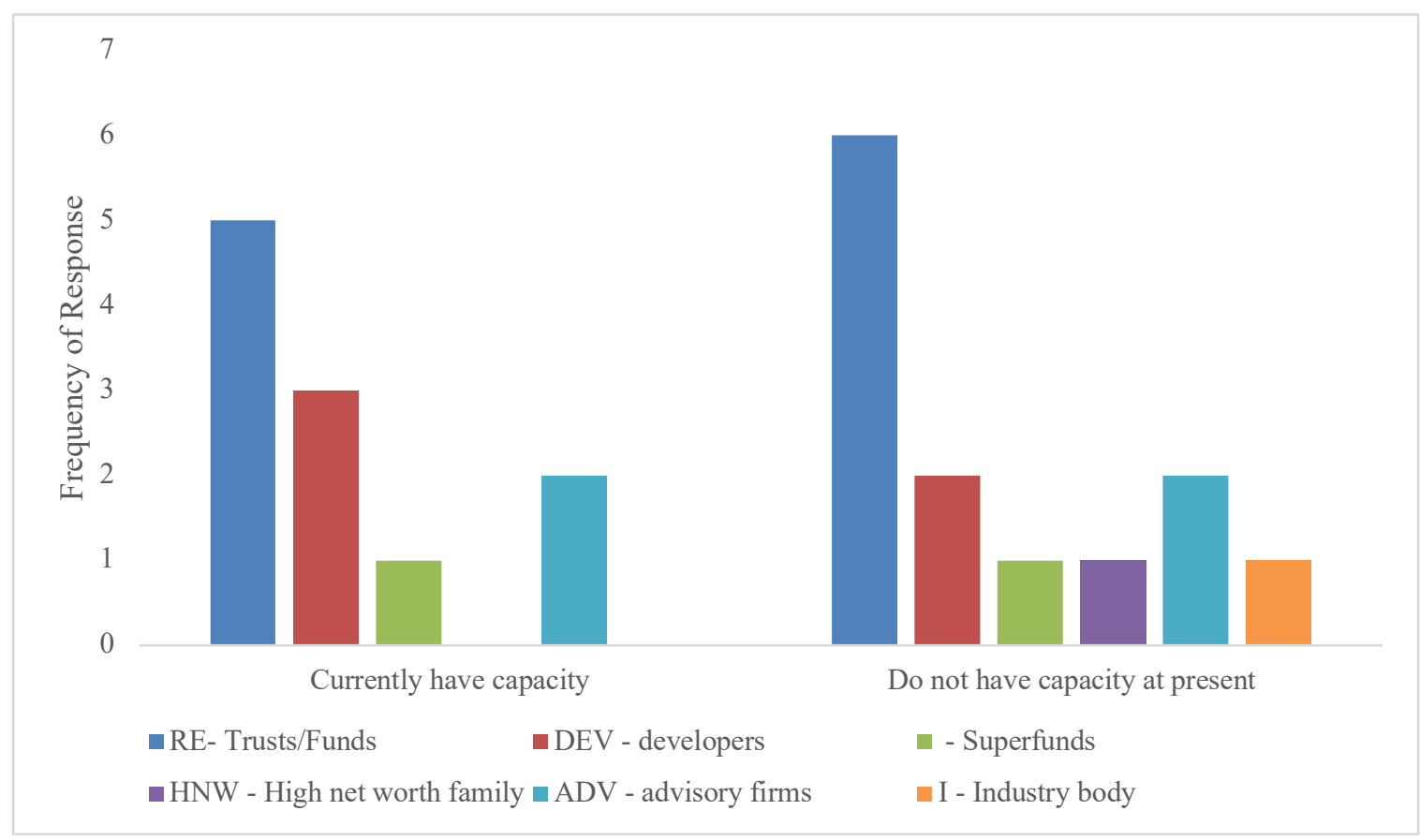

Eleven respondents indicated yes they did have capacity, but there were variations about how they considered they were doing this, with clear actions being taken by some. Examples of the breadth of responses can be found below:

"When you say capacity, I see that as people, processes and tools. So we - firstly in terms of people, obviously we've got a sustainability team headed by [anonymous]. We work quite collaboratively internally with risk on - I guess climate change risk - as well as operations in terms of our response. We're also quite engaged with our procurement team and our developments and transactions 
team as we need to. So, there's a cohort of people across the business that are learning in relevant to their business unit and role to help us better understand the situation and to take - to bring learnings in and to take projects forward." (RE6)

"I would say that that is 90 per cent of my job. It's all about messaging, and it's all about how I receive information, or our team receives information. Then we have to look at, very, very carefully, how do we influence the business." (RE7)

"We built almost like a physical risk scenario asset model for each of our assets that we own and manage" (RE11)

"We've got a governance structure in place where we put the resources behind it." (RE9)

The research found that certain firms appear to be motivated more by external influences like the Task Force on Climate-Related Financial Decisions (TCFD) and Green Star ratings, driving an increased need and capacity, which has then led to further climate change consideration and risk analysis:
"We're starting that journey, I think, properly now, because of what I've said about the risk register and climate change now coming on board with that. I think where we've done quite a bit of work is in the residential community space, where again a legacy with Green Star is that we have to create these community resilience plans." (DEV2)
"We've just done the TCFD review and so now what we're looking at doing is, how do we bring that information into the due diligence." (RE7)

Two of the advisory firms indicated they had the capacity and resources to allocate to these information translation tasks, with clear indications that they kept up to date with information. For several of the interviewees' organisations, climate change is the responsibility of, and embedded within their sustainability teams. For others, while they had capacity, the actual translation at present was unclear.

Thirteen respondents indicated they did not presently have the capacity to translate climate change information into their organisational practices, with little justification in most cases. This included six RE trusts/funds, one of the superfunds, the high net worth family, the industry organisation, two advisory firms, and two of the developers:

\begin{abstract}
"It's never anything that I've been asked to undertake. It's such a specialist niche area that it's, as I said, within my organisation in terms of the servicing of clients is largely sitting within property and asset management." (ADV3)
\end{abstract}

"Look I think the short answer is no, not really." (RE2)

For some interviewees a due diligence checklist was utilised, but climate change aspects were not considered because it was beyond the 15-year timeframe (RE1, HNW1), although they did consider current flooding, insurance, fire and solar panels. Others mentioned that when it became an issue, they'd engage consultants (RE4), and RE5 indicated there would be a process in future and there had been discussion but there was no formal capacity and direction yet. This resonates with Shearer et al's (2016) Australian study that found smaller organisations relied on consultants to provide them with such information and due diligence.

\title{
Opportunities for learning about climate change
}

The respondents were asked about opportunities to increase learning and understanding of climate change. Overall, there was desire for more CPD and conferences, events and training courses (11), this 
was found to be consistent with an Australian construction industry study by Hurlimann et al. (2018a). Subsequently, there was demand for more extensive and representative climate change data (5); standardised climate change risk assessment and management (3); and industry networks and committees (1). Whilst one respondent indicated regular media consumption was sufficient, there were three others who saw no need for additional learning opportunities. Given Walter et al.'s (2003) review of literature about communication of scientific information about climate change and the best methods of doing so includes the dissemination of this information in accessible forms - these identified mechanisms above, could be used as a starting point for dissemination.

RE8 suggested that perhaps in creation of future events and training, that the word 'climate change' shouldn't be used, and 'resilience' should instead be used with a focus on solutions, rather than further highlighting of risks, because in their experience, people and their company board were more receptive to solutions than risks. This may address some of the issues identified in Howlett's (2014) research that discuss the 'low visibility and low intentionality' of climate change, that facilitate the implementation of negative strategies of denial and attack by governments. Although we did not explore respondents' perceptions of climate change directly, if they perceive it is not an issue that affects their company, they may be motivated to deny it, rather than positively address it, as suggested by Howlett (2014).

\section{Summary and discussion}

The results of interviews with a range of actors within Australia's property industry reveal that there is great variation in the types of climate change information sourced, and how this information is then used and applied. This variation exists within our sample, which in itself may not reflect a cross section of the industry, due to a number of invited industry stakeholders declining to be interviewed for this research (see limitations). This suggests that there is substantial variation in the preparedness and capacity for the property industry to address climate change adaptation. Given the economic, social and environmental imperatives for urgent climate change action, this research highlights key needs for more effective science-practice collaborations, to assist in the provision of timely, rigorous and industryrelevant information, which is in line with previous research. The results also highlight the needs for increasing the climate change 'literacy' of industry participants, to ensure effective decision-making on investment choices, building design, construction and management for the built environment. Perhaps as climate change becomes more visible and tangible to the activities of property and real estate companies (see Howlett 2014), motivation to address the challenges in positive and constructive ways will increase.

\section{Conclusion}

This paper has explored climate change information use and needs of key stakeholders in the Australian property industry. The study found that about a third of the key stakeholders interviewed (7) did not actively seek information about climate change. Others kept informed through incidental or widely accessible, non-scientific sources such as mass media (4). However, some industry actors actively pursued more detailed information about climate change through industry networks and committees in which they are involved and government reports (6), while others actively sought rigorous scientific and research based information and applied it to their activities (7).

The most trusted sources of information were industry rating systems (and their organisations) (29), followed by Australian Government sources (19) and international organisations (14). The respondents expressed a need for more information about the impacts of climate change, from credible sources that can be utilised and accessed at a national level. These results provide information to scientists about the best pathways to communicate the science of climate change to property/real estate stakeholders in Australia. They also highlight a greater role for the government in providing guidance and standards. The characteristics of climate change as a 'low visibility and low intentionality' issue at present, may explain a lack of leadership from the government in proactively addressing climate change through these mechanisms at present. Eleven respondents indicated they thought their organisation had capacity to translate such information into decision making, which indicates there are future opportunities for 
scientific information to influence practice in this way. In comparison 13 indicated that they thought they did not. Those with sustainability teams in-house appeared to express greater capacity. In terms of future opportunities for learning about climate change impacts in the property industry, CPD events were most commonly cited as potentially most useful (11) whereas three respondents thought there was no need.

Overall, the results indicate the important role played by industry standards and industry associations as communication channels about climate change in the Australian property industry. The results indicate that there is great potential to increase and strengthen the information provided to industry, and in turn utilised and applied by the industry. Facilitating this through industry-trusted sources is particularly important, and would suggest that climate change scientists should partner with such organisations to disseminate relevant information, in formats that would be most useful to industry. It will likewise be important to facilitate capacity to translate this information into practice and everyday decision making. This paper provides guidance on how this might be achieved, and thus contributes to increasing the potential for effective climate action in the built environment. While the study was located in Australia, it will potentially have relevance for other contexts, particularly those with similar development contexts, in the absence of detailed published research in this field. Further research to confirm these findings in a quantitative manner, and in other contexts would be beneficial.

\section{Acknowledgements}

We acknowledge the research assistance with the data analysis provided by Laura Cutroni. The research was funded through a Research Development Grant from the Faculty of Architecture Building and Planning at the University of Melbourne, Australia.

\section{References}

Commercial Building Disclosure Program. (2019). "Program Statistics". Government of Australia: Canberra.

Dunn, G., Brown, R. R., Bos, J. J., and Bakker, K. (2017). "The role of science-policy interface in sustainable urban water transitions: Lessons from Rotterdam." Environmental Science and Policy, 73, 71-79.

Eriksen, S., Øyen, C., Kasa, S., and Underthun, A. (2009). "Weakening adaptive capacity? Effects of organizational and institutional change on the housing sector in Norway." Climate \& Development, 1(2), 111-129.

Fuss, S., Canadell, J. G., Peters, G. P., Tavoni, M., Andrew, R. M., Ciais, P., Jackson, R. B., Jones, C. D., Kraxner, F., Nakicenovic, N., Le Quéré, C., Raupach, M. R., Sharifi, A., Smith, P., and Yamagata, Y. (2014). "Betting on negative emissions." Nature Climate Change, 4(10), 850853.

Head, B. W. (2008). "Three Lenses of Evidence-Based Policy." Australian Journal of Public Administration, 67(1), 1-11.

Head, B. W. (2016). "Toward More "Evidence-Informed" Policy Making?" Public Administration Review, 76(3), 472-484.

Howlett, M. (2014). "Why are policy innovations rare and so often negative? Blame avoidance and problem denial in climate change policy-making." Global Environmental Change, 29, 395403.

Hurlimann, A., Browne, G., Warren-Myers, G., and Francis, V. (2018a) "Facilitating climate change adaptation in the Australian construction industry - identification of information needs " Presented at Proceedings of the 4th Practical Responses to Climate Change Conference: "Climate Adaptation 2018: Learn, Collaborate, Act",, Melbourne.

Hurlimann, A. C., Browne, G. R., Warren-Myers, G., and Francis, V. (2018b). "Barriers to climate change adaptation in the Australian construction industry - Impetus for regulatory reform." Building and Environment, 137, 235-245.

Hurlimann, A. C., Warren-Myers, G., and Browne, G. R. (2019). "Is the Australian construction industry prepared for climate change?" Building and Environment, 153, 128-137.

Intergovernmental Panel on Climate Change. (2018). Global warming of $1.5^{\circ} \mathrm{C}$. An IPCC special report on the impacts of global warming of $1.5^{\circ} \mathrm{C}$ above pre-industrial levels and related 
global greenhouse gas emission pathways, in the context of strengthening the global response to the threat of climate change, sustainable development, and efforts to eradicate poverty In Press. Viewed 10/11/18 at: http://www.ipcc.ch/report/sr15/.

Iyalomhe, F., Jensen, A., Critto, A., and Marcomini, A. (2013). "The Science-Policy Interface for Climate Change Adaptation: the Contribution of Communities of Practice Theory." Environmental Policy \& Governance, 23(6), 368-380.

Mallon, K., McKinlay, M., Haughton, N., Hamden, R., Tedder, R., and Lamb, J. (2019). Climate change risk to Austalia's built environment: A second pass National Assessment Australia, XDI Pty Ltd and Climate Risk Pty Ltd.

Moser, S. C., and Luers, A. L. (2008). "Managing climate risks in California: the need to engage resource managers for successful adaptation to change." Climatic Change, 87, 309-322.

Property Council of Australia. (2015). Letter Jennifer Cunich to Climate Change Act Review Secretariat, 30th July 2015 Re: Review of the Climate Change Act 2010. Property Council of Australia, Melbourne.

Ryan, P. (2019). "Climate change could slash $\$ 571 \mathrm{~b}$ from property value, study warns" $A B C$ News, $9^{\text {th }}$ May. Viewed 28 April 2020 at: https://www.abc.net.au/news/2019-05-09/climate-changecould-wipe-571b-off-property-values/11096768

Shearer, H., Coiacetto, E., Dodson, J., and Taygfeld, P. (2016). "How the structure of the Australian housing development industry influences climate change adaptation." Housing Studies, 31(7), 809-828.

Storbjörk, S., Hjerpe, M., and Isaksson, K. (2018). "'We cannot be at the forefront, changing society': exploring how Swedish property developers respond to climate change in urban planning." Journal of Environmental Policy \& Planning, 20(1), 81-9.

Taylor, B. M., Harman, B. P., Heyenga, S., and McAllister, R. R. J. (2012). "Property Developers and Urban Adaptation: Conceptual and Empirical Perspectives on Governance." Urban Policy and Research, 30(1), 5-24.

Taylor, E. J., and Hurley, J. (2016). "“Not a Lot of People Read the Stuff”: Australian Urban Research in Planning Practice." Urban Policy and Research, 34(2), 116-131.

The British Academy. (2008). Punching Our Weight: The Humanities and Social Sciences in Public Policy Making. The British Academy, London.

Tribbia, J., and Moser, S. (2008). "More than information: what coastal managers need to plan for climate change " Environmental Science \& Policy 11(4), 315-328.

UN-HABITAT. (2011). Cities and Climate Change: Global Report on Human Settlements 2011, London: Earthscan.

United Nations. (2015). Paris Agreement, Viewed on line 2/11/2017 at: http://unfccc.int/files/essential_background/convention/application/pdf/english_paris agreeme $\underline{\text { nt.pdf }}$

United Nations Environment Program. (2019). Emissions Gap Report Nairobi: UNEP.

van den Hove, S. (2007). "A rationale for science-policy interfaces." Futures, 39(7), 807-826.

van Stigt, R., Driessen, P. P. J., and Spit, T. J. M. (2015). "A user perspective on the gap between science and decision-making. Local administrators' views on expert knowledge in urban planning." Environmental Science \& Policy, 47, 167-176.

Walter, I., Nutley, S., and Davies, H. (2003). Research Impact: A Cross Sector Review - Literature Review. University of St. Andrews, St Andrews.

Warren-Myers, G. (2016). "Sustainability evolution in the Australian property market: Examining valuers' comprehension, knowledge and value." Journal of Property Investment \& Finance, 34(6), 578-601.

Warren-Myers, G., Hurlimann, A., and Bush, J. (2020). "Barriers to climate change adaption in the Australian Property industry." Journal of Property Investment \& Finance. https://doi.org/10.1108/JPIF-12-2019-0161

Weichselgartner, J., and Kelman, I. (2014). "Geographies of resilience: Challenges and opportunities of a descriptive concept." Progress in Human Geography, 39(3), 249-267. 


\section{University Library}

\section{- M M I N E R VA \\ A gateway to Melbourne's research publications}

Minerva Access is the Institutional Repository of The University of Melbourne

Author/s:

Warren-Myers, G;Hurlimann, A;Bush, J

Title:

Advancing capacity to adapt to climate change: addressing information needs in the Australian property industry

Date:

2020-06-18

Citation:

Warren-Myers, G., Hurlimann, A. \& Bush, J. (2020). Advancing capacity to adapt to climate change: addressing information needs in the Australian property industry. Journal of European Real Estate Research, 13 (3), pp.321-335. https://doi.org/10.1108/ JERER-03-2020-0017.

Persistent Link:

http://hdl.handle.net/11343/248494 